\title{
Interculturality in Teacher Education in Times of Unprecedented Global Challenges
}

\begin{abstract}
As societies face unprecedented challenges that are global in scope and 'more-thanwicked' in nature, educators and educational policy makers emphasize the importance of deepening knowledge about the causes of these problems, creating policies to address them more efficiently, and offering more compelling moral arguments that might persuade people to change their convictions, and, as a consequence, their behaviour. These concerns shape how policies on the study of interculturality is approached in contemporary teacher education in our contexts in Canada and the UK. Our research, however, positions these as problems that cannot be solved with improved information, enhanced cross-cultural skills, or moral claims, because they are rooted in modernity's systems that structure the possibilities for co-existence on the planet. We see these problems as ontological challenges of being that emerge from a modernist ontology rooted in colonial violences. Our approach therefore explores an orientation to intercultural education which enables student teachers to expand their understanding of cultural and ecological relationships beyond existing frameworks of modernist knowledge, politics, and economic systems. In this paper, we share some of our current learning about the affordances and limitations of dominant approaches to intercultural education, and then explore how the method of 'social cartography' can enable engagement with ontological problems in teacher education which generate possibilities for imagining decolonial learning futures, beyond modernity.
\end{abstract}

Keywords: teacher education, intercultural education, modernity, decolonial futures, global challenges

Running head: Intercultural ITE and global challenges

Sarah Amsler, University of Nottingham

sarah.amsler@nottingham.ac.uk

Jeannie Kerr, University of Winnipeg

je.kerr@uwinnipeg.ca

Vanessa Andreotti, University of British Columbia

vanessa.andreotti@ubc.ca 


\section{Introduction}

'Despite unquestionably good intentions on the part of most people who call themselves intercultural educators, most intercultural education practice supports, rather than challenges, dominant hegemony, prevailing social hierarchies, and inequitable distributions of power and privilege' (Gorski 2008, p. 515)

This paper begins from a concern that while dominant forms of intercultural education are well intentioned, they often reinforce particular forms of modern violence that intercultural educators are working to address (Gorski 2008). In our view, prevailing modes of interculturality in education not only discourage teacher candidates from engaging with the root causes in modernity of the unprecedented global challenges we face today, but also entrench ways of knowing and being that make these roots invisible and therefore difficult to address. In this paper, we explore how interculturality might be re-imagined as an approach to interrupting harmful patterns of social and ecological violence, and consider the affordances and limitations of this work in teacher education in our two Anglo-North contexts, Canada and England. We detail this argument before sharing an alternative approach that emerges from our pedagogical research within the transnational Gesturing Towards Decolonial Futures Collective (hereafter GTDF). ${ }^{1}$ These pedagogical experiments, which engage an ontological understanding within learning, aim to help educators in these contexts expand their capacities for 'digging deeper and relating wider' beyond modernist frameworks in their understandings of and responses to global challenges (Andreotti, Stein, Suša, Cajkova, d'Emilia, Jimmy, Calhoun, Amsler, Cardoso, Siwek \& Fay, 2019). We conclude by illustrating how using methods of 'social cartography', and the posture of the 'gesture', can help educators in our contexts embrace a kind of ontological openness that gestures beyond modernity's harms and violences, and towards forms of interculturality that cannot yet be imagined.

\section{Interculturality's Reproduction of More-Than-Wicked Problems through Modernity's Ways of Being}

Today, teachers worldwide are expected to 'acquire a nuanced global perspective of their subject areas and be prepared to handle the demands of educating students for our changing global context' (Schwarzer \& Bridglall, 2015; see also Shallcross \& Robinson, 2007). However, they are also increasingly responsible for helping children and young people understand and respond to complex social, economic and ecological problems on a global scale. Widespread ecological destruction and species extinctions, mass and forced migration and displacement, violent conflict, political polarisation and volatility, compromised democracy, gross inequality affecting economic insecurity, and ongoing knowledge and language loss changing - and threatening - the world that young people learn in and about. They are not only 'difficult knowledges' in their reference to social breakdowns (Pitt \& Brtizman, 2003), but 'wicked problems' that defy singular description or explanation, are not definitively solvable, do not conform to scientific criteria of truth, and are not empirically testable in reliable ways. Indeed, we argue that they are even more-than-wicked because they are rooted in harmful patterns of modernist (and, as we explain below, therefore colonial) ways of knowing, relating and being, and therefore cannot be resolved with the ways of thinking or 'single solutions' that modernist education itself prepares us to devise (Grosfoguel, 2012, p. 85). 
Since the 1980s, knowledge about and capabilities for 'interculturality' have been prominent concerns in both local pedagogical practices and educational policy-making at national, international and supranational levels. New forms of 'intercultural education' gained momentum as the twenty-first century unfolded into environmental crisis, global conflict, migration and political polarities (Faas, Hajisoteriou, \& Angelides, 2014). Yet as Fred Dervin argues, while "the "intercultural" is now omnipresent in most departments of teacher education in Europe and elsewhere' in a variety of forms, it is still often based upon essentialised and static understandings of 'culture' which are colonial in origin and nature (Dervin, 2015, p. 71). Thus, while interculturality in education is positioned to tackle questions of equity, diversity and inclusion in global contexts in which more-thanwicked problems are enmeshed, these discussions often happen without proper consideration of issues of deep unsustainability - in the same way that discussions of unsustainability often fail to take adequate account of issues of equity, diversity and inclusion. This gap often results in approaches that reproduce simplistic solutions to complex problems, and ethnocentric and paternalistic relationships. Dominant approaches to interculturality' in teacher education offer a simplistic focus on 'culture' and communication across assumed cultural divides, focusing on problems of access, opportunity or anti-racism at best. In this view, interculturality understands 'culture' as a noun that refers to the content of others' belief systems, attitudes, values and behavioural attitudes which can be acquired in order to exchange information and relate across constructed borders that are perceived as natural, rather than as a verb that refers to the process of the historical construction of the 'normal' and of the separation of 'us' from 'them'.

This logic is evident in high-level global policies, as exemplified by UNESCO's (2006) publication of guidelines on intercultural education which suggested that

'in a world experiencing rapid change, and where cultural, political, economic and social upheaval challenges traditional ways of life, education has an important role to play in promoting social cohesion and peaceful coexistence',

and more specifically arguing that

'the governability of pluralistic, democratic societies increasingly depends on the capacity of governments to provide equity in public and social life, and to educate citizens who are open to intercultural dialogue and tolerant of each other's ways of being and thinking' (UNESCO, 2006, p. 8).

This broad agenda encompasses a range of educational efforts around the world. These include developing interculturality as a form of social justice education, in the work of Gorski (2009); Morris (2013); Ochoa (2010) and Quin (2009), specifically in the fields of plurilingual learning (Antier, 2019; Antunes, Teixeira \& Cruz, 2009) and digital and social media learning technologies (Dooly 2011; Magos, Tsilimeni \& Spanopoulou, 2013). In teacher education, there are initiatives to cultivate difference-curious sensibilities among preservice teachers who participate in cross-cultural placements and exchanges (Driscoll, Rowe \& Thomae, 2014); counter 'unconscious bias' and (to a lesser extent) whiteness and white supremacy in teachers' worldviews and identities (Boscardin, 2015; Martin \& Pirbhai-Illich, 2016); and deepen minoritized people's rights and equalities in Other veins of scholarship in intercultural education focus on the economic use of 
developing 'transferable skills' for global mobility and 'employability' (Jackson, 2015; Messelink, van Maele \& Spencer-Oatey, 2015) and the diversification of student populations and school and university curricula through 'inclusion' and 'internationalisation' agendas and processes (Jiang, 2011; Pagani, Robustelli \& Martinelli, 2011).

While these examples are selective, they indicate that dominant approaches to intercultural education policy and practice often assume that the existing order of global social relations is desirable, but should (and can) be made more equitable, cohesive and sustainable. This framework also reflects a notion that multicultural societies are comprised of people who are separated from one another only because they lack personal connection or affective dispositions towards mutual understanding of individual and cultural differences. This analysis lends itself to assumptions that teaching rational, democratic dialogue, new emotional competencies or the acquisition of intercultural skills will enable these groups to peacefully co-exist while more critically engaging with common problems. The limitation of this approach is that it does not recognise or enable us to develop capabilities to address the root causes of our gravest social divisions, hierarchies, inequalities and injustices, which lie in patterns of systemic, colonial violence. Instead, it contains the transformative potential of interculturality within a 'modern/colonial global imaginary' which, like all social imaginaries,

'restricts intelligibility: what lies outside of it is not what we do not imagine, but what we cannot imagine from within it. Thus, even when we critique aspects of the imaginary that we find problematic, our proposals for alternatives (in order to be intelligible) tend to, paradoxically, remain within it' (Andreotti \& Pashby, 2016, p. 774).

Within this imaginary, the problems of the present are interpreted as either methodological challenges that can be resolved through developing and applying more effective individual techniques, skills, policies and organisational strategies, or as epistemological challenges that can be overcome by generating and analysing more data, obtaining new information or perspectives, and creating new theories. In both cases, the underlying modern/colonial way of being is not questioned. ${ }^{2}$

What the globally hegemonic vision of intercultural competency renders unintelligible is that enduring divisions and forms of human domination (of the human and more-thanhuman beings of the planet) are not due simply to problems of ineffective communication or unfamiliarity. Thus, the pervasive strategies in intercultural education that seek to address domination by promoting deeper understandings of the 'other', or patronizing attempts to take care of the 'other' obscure the deeper forces that make othering possible. Indeed, the prioritisation of rational debate and conscious behaviour change in intercultural education is only made possible by the delegitimization, devaluation and invisibilization of other ways of knowing and being - specifically, the invisibilizing of non-Eurocentric orientations that work to interrogate the colonial violences that are reproduced in educational relationships today (Bhambra \& Holmwood, 2018; Tomlinson, 2019).

Mainstream approaches to intercultural learning are based on three 'pillars' of modernist ontology that are themselves generally invisible to those being supported by them (Hartley, 2000). The first pillar is certainty - that 'through theory and empirical research, 
we can come to understand the world', and this understanding will then enable change for the better (Hartley, 2000, p119). The second pillar is formal rationality - that we can make this change by applying rules, laws and regulations to our thinking and practice. The third pillar is the myth of the clean slate - the practice of setting aside history and power, to emerge in a state of innocence (of participating in systemic harm) or redemption. Through this approach, we are released from responsibility for the creation of the problem and our ongoing entanglements with it. Working in a structure that is supported by these three pillars, we can only create solutions to global challenges which are both more 'interculturally competent' and contribute to the reproduction of violent systems of epistemic, existential, and geopolitical domination. This is because such discourses of interculturality are rooted in what Stein et al. refer to as 'fantasies of ontological security', or stories where modern entitlements are promised through global capitalism, nation state structures, and Enlightenment humanism. These stories particularly animate the white Anglo-European subject and, 'more broadly, the modern liberal subject' in education (Stein 2017, p. 4).

In other words, experiences of intercultural dissonance and conflict that are rooted in ontological difference and systemic violence cannot be addressed through developing deeper understandings of 'other cultures' (or simply becoming aware that there are multiple ways of being), acquiring culturally specific knowledge or basic language skills, 'cross-fertilising' experiences, heightening sensitivities to 'cultural difference' or increasing tolerance for what is experienced as 'other'. Therefore, any 'brand of intercultural education, in which we focus on interpersonal relationships and cultural awareness, leaves the power hierarchy firmly in place - even within our intercultural practice. This is exactly the kind of diversion that serves the colonizing and neo-liberal interests of the powerful' (Gorski, 2008, p.521).

It may be tempting to define intercultural education as an inherent attempt to interrupt these perceived entitlements and desires, particularly when it aims to enable people to go 'beyond passive coexistence, to achieve a developing and sustainable way of living together in multicultural societies through the creation of understanding of, respect for and dialogue between the different cultural groups' (Zilliacus \& Holm, 2009, p. 2). We argue, however, that all of this can be technically learned yet continue to perpetuate three modern harms: (1) a mode of existence that does not (and needs not to) address systemic epistemological, affective and material injustice; (2) a way of being in which it is possible to separate humans into discrete and hierarchical categories in relationship to each other and the more-than-human being in the first place; and (3) a form of educational response that encourages intercultural co-operation without demanding engagement with 'the cognitive, affective, and relational economies that have left us unprepared and unwilling to address our complicity in systemic harm, or face the magnitude of the problems that we have ahead of us' (Andreotti et al., 2018),

What is at stake is the problem of how to be and become otherwise in ways that, from within modern societies, are not yet either imaginable or feasible. As we recognize our immersion in neoliberal capitalism, rampant consumerism, geo-political power struggles of knowledge and land, and a growing military-industrial complex (Escobar, 2018), how can we imagine something else? While this deeper analysis and questioning has been the starting point for both research and political action in postcolonial, decolonial, feminist, critical race and Indigenous educational studies for decades, it still does not circulate widely in discourses about policy, curriculum design or pedagogy in teacher 
education in our Anglo-North contexts. Here, debates about how to prepare teachers for ' $21^{\text {st }}$ century education' rather tend to be premised upon some combination of normalised neoliberal values (e.g., entrepreneurial individualism, competition and commodified knowledge); key Enlightenment principles such as economic and human development, equality, freedom, humanism, mobility, progress and rationality; and the presumed universality and necessity of modernity's organisational pillars of capitalism and the nation-state, upon which schools and universities currently depend (Andreotti, et al 2015).

Those teaching and learning within the framework of this social imaginary have few opportunities to see, and even fewer to sit with the discomfort of facing, not only that modernity has a violent underside, but that much of what is normalised, desired and rewarded as good education belongs to and reinforces 'historical patterns that have cultivated unsustainable and harmful forms of collective relationships and have limited human possibilities for imagining (and doing) otherwise' (Andreotti, 2012, p. 19; Simpson, 2014). This creates what we have defined as more-than-wicked problems. As Walter Mignolo (2011) argues, while Western European modernity has been constructed as both the zero point and the arrival point of human existence and history, it only exists by hiding the colonial violences that make it possible. As part of this history, the harmful patterns that are reproduced in teacher education in our contexts remain invisible not because teachers have an impoverished imagination of what is possible, but because they cannot access other ways of thinking, doing and being that reveal the limits of what is imaginable within the very systems that offer them satisfaction and security, and that invite them to gesture beyond them. This therefore raises a critical pedagogical question: how is it possible to make the limits of the modern/colonial imaginary visible?

\section{Social Cartography: A Methodology for Addressing Ontological Commitments in Intercultural Education}

The remainder of this paper explores a methodology - 'social cartography' - that we argue can catalyze movement towards 'decolonial' modes of intercultural teacher education. By 'decolonial', we refer to ways of understanding and approaching cultural practices in education that interrupt harmful ways of being that are rooted in modernity's social and ecological violences. Within a decolonial approach, we seek to trouble the dominance of white, Eurocentric categories and problem-definitions (including taken-forgranted assumptions about the value of capitalism, the nation-state, and universal reason). We call attention to androcentric, ethnocentric and paternalistic educational relationships, and interrupt the related desire for simplistic pedagogical solutions that 'forget' colonial presence and histories. In this approach, we expand our relational responsibilities within an ecological approach that recognizes the human and more-thanhuman as related (Donald, 2016; Kerr \& Andreotti, 2018).

Social cartography is a tool that visualises the range, limitations and practical implications of different (including both dominant and marginalised) ways of framing a phenomenon and allows people to explore relationships between diverse orientations and imagine what is beyond their edges (Andreotti et al. 2016; Andreotti \& Suša 2019). It is especially useful in contexts where dominant ways of knowing are naturalized as singular or true (in this case, modern/colonial imaginaries of 'interculturality') and others are delegitimized or rendered invisible (here, both foundational critiques of modernity and its existing and possible alternatives). We have illustrated above how 
modern/colonial discourses situate even critical approaches to interculturality in teacher education within a container that both reproduces epistemic and social violence and renders alternative frameworks undesirable or unintelligible. Social cartographies allow us to 'map' these approaches as part of a wider discursive field of potential meanings of 'the intercultural' in a way that enables teachers to recognize the limitations of modern/colonial frames of reference, confront their everyday investments and complicities in these frames, and encounter the possibilities of different, more relational, ways of knowing and being. This, in turn, fulfils a major aim of the social cartographic method to facilitate dialogical exploration of the edges of what are usually 'taken as implicit theoretical, political, epistemological and ontological assumptions' about a complex issue to facilitate conversations that transcend paradigmatic orientations and investments (Andreotti et al. 2016, p. 87).

Our approach to social cartography draws on the work of Rolland Paulston and Martin Lieberman in international and comparative education (Lieberman and Paulston 1996; Paulston 2009; Paulston and Lieberman 1994; Rust and Kenderes 2011) and recent research conducted by members of the GTDF collective into critiques of modern educational systems (Stein et al. 2017); multiculturalism in teacher education (Andreotti et al. 2014, Kerr \& Andreotti, 2019), projects to decolonize higher education (Andreotti et al. 2015), higher education research (Andreotti et al. 2016; Stein 2019a, 2019b), higher education policy (Andreotti and Pashby 2016); educational internationalization (Andreotti et al. 2016), and the paradoxes and challenges of Indigenous education (Ahenakew 2017). In this paper, we illustrate how cartographies that have been developed through this research can also enable teachers who are learning about interculturality to expand their imagination of cultural and ecological relationships and responsibilities beyond existing frameworks of modern knowledge, politics and economic systems.

\section{Three cartographies that trouble modern/colonial approaches to interculturality in teacher education}

Below, we introduce three cartographies that we use when working with teacher candidates in our contexts. The first is a metaphorical image of 'the house of modernity' which visualizes the colonial violences inherent in the relationships within our systems of modern living. The second is a map of affective dispositions towards crossing epistemological and cultural borders (represented by visual metaphors of ways to travel), and the third a map of affective dispositions towards complexity in engagements with cultural and global problems (represented by the visual metaphor of a beach). These cartographies allow us to pursue four efforts that can enable gestures beyond modernity in intercultural education: first, problematizing common-sense conceptions of 'interculturality' by situating them in a broader ecology of knowledges; second, expanding the range of available discourses about interculturality, particularly including those that operate without and beyond modern Eurocentric epistemologies; third, engaging directly with people's affective and material investments in modern/colonial ways of knowing; and fourth, exploring the existing and possible relationships between these knowledges and the ways of being - here, the ways of 'doing intercultural education' - that they facilitate (Andreotti et al. 2016; Andreotti and Suša 2019). This method, we argue, creates possibilities to engage with the complexities of modernity, intercultural relationships and 'more-than-wicked' social and global challenges in ways that are not pre-determined, but emerge from examining their own lived subjectivities and complicities (Martin \& Pirbhai-Illich, 2016). It specifically invites direct engagement 
with the cognitive, affective and relational dimensions of everyday educational practices that perpetuate the systemic harms of modernity, and offers a generous range of entry points to this work for teacher candidates who come to it with differing levels of openness. In doing so, this method can further 'open up meanings, to uncover limits within cultural fields, and to highlight reactionary attempts to seal borders and prohibit translations' that can enable teachers in our contexts to engage with ontological problems and generate possibilities for re-imagining interculturality beyond modernity (Paulston, 2009, p. 977).

\section{Cartography 1: The house that modernity built}

This cartography invites reflection on the complex notion that while the major global challenges we now face 'are often perceived to derive from external, exceptional threats to the house....in fact [they] are a product of the violent and unsustainable practices that are required in order to build and sustain the house itself' (Stein, Hunt, Suša \& Andreotti, 2017). These include, as discussed above, three 'pillars' of modernity upon which mainstream approaches to intercultural learning are often premised: epistemological certainty, the supremacy of formal rationality over other ways of knowing and being, and the myth of a modern liberal educational subject who is innocent of participating in systemic harm. While it appears to some people (particularly those living within the 'north of the global north' and 'north of the south', as illustrated in Fig. 1) that the house is suddenly crumbling, the image evokes how its stability and desirability have always been made possible by the exploitation and appropriation of the earth and most of its inhabitants.

[insert figure 1: The house modernity built (excerpt from https://decolonialfutures.net/portfolio/mini-zine-house-mycelium/ )]

This cartography enables us to raise a number of questions that are often rendered unthinkable in formal education contexts, such as: What learning can interrupt the circuits of power that hold systemic cultural violence in place today? How can educational desire be reoriented away from sustaining harmful social relations that benefit some towards confronting the problems that may have set humans on a path not only of intercultural conflict, but towards extinction? Working with this cartography enables us to construct an intercultural educational orientation that does not see the problems of the present as rooted in methodological deficiency (i.e., the need for more effective strategies, policies and communications) or epistemological deficit (i.e., requiring more data, information, knowledge or perspectives). Rather, it orients us towards ontological problems of how we are, of being. It centres the question: how do we exist together and how might we exist otherwise in relation to both each other and the planet? Using this cartography, we can explore how intercultural education may be oriented towards expanding social and ecological responsibilities beyond fixed, rational categories associated with social difference, economic markets, nation states, universal reason and liberal democracy, and specifically beyond the ontological security that these promise.

Working with this cartography, however, may evoke uncomfortable reflections on our existing knowledge of and investments and complicities in these fundamental systems of modern life, and we have found that teacher candidates often experience it as cognitively and emotionally challenging. In the following sections, we therefore introduce two additional cartographies that can support people to 'dig deeper and relate wider' into the complexities of our efforts to engage with interculturality in other, more decolonial 
ways. These cartographies, which have been created on the basis of pedagogical and theoretical research conducted by members of the collective, do not provide teacher candidates with theoretical models or practical checklists for intercultural work, or offer clearly defined solutions to the 'more-than-wicked problems' they may face. They rather facilitate reflections on and conversations about the production and interruption of patterns of modern/colonial harm in educational thinking and practice.

\section{Cartography 2 - Border-crossing dispositions: house, caravan, tent and hat}

The cartography 'Four dispositions for crossing borders' emerged from a research project in Finland that aimed to evaluate global mindedness in government-funded education exchange programs, such as Erasmus (Andreotti, Biesta, \& Ahenakew, 2011). The current version of this cartography (Fig. 2) shows the limits of current intercultural approaches and gestures towards a form of intercultural (teacher) education that can open existential possibilities to address complexities, uncertainties, and inequalities of/in global engagements. The term 'borders' here extends beyond the geographical to include affective, intellectual, relational, political, economic and ecological practices of boundary making and border crossing. The cartography uses four metaphors to visualise some common dispositions towards border crossing, or engaging with the other and the unknown, each of which has different implications for intercultural thinking and practice. The metaphors for border crossing dispositions are: 1) a gated house, which represents a desire to avoid border crossing and keep oneself closed off and protected; 2) a caravan, which represents a desire to cross borders, but entirely on one's own terms without fundamental personal change; 3) a tent, which represents a desire to engage and cross borders with more openness to what is other, as well as a desire to maintain the pre-eminence of one's own way of going about things; and 4) a straw hat, which represents a desire to cross borders and fully engage with what is other with almost complete openness to new possibilities. These metaphors are not meant to be interpreted as a linear, developmental model of 'intercultural capacity building', but rather to facilitate the development of a meta-language for self-awareness, selfreflectivity and self-reflexivity in intercultural contexts.

[insert Figure 2: Border-crossing dispositions: house, caravan, tent, hat]

This cartography suggests that all learners have the four dispositions within them to different degrees, and that our dispositions may vary and change depending on a range of contextual factors. However, it also suggests that modern forms of intercultural education focus on strengthening the caravan (or, at best, the tent) disposition, and mostly ignore the possibility of the hat. Intercultural teacher education strategies that strengthen the 'hat' disposition could prepare teachers to engage with the complexities, uncertainties, paradoxes and difficulties of intercultural engagements, with the heterogeneity of diverse communities and of the dynamics of unequal relations of power. While the caravan disposition feeds desires for the universalization of one set of values and a deficit theorization of different worldviews, the tent disposition feeds desires for a different type of universalization that seeks a 'rainbow' merger of selective nonthreatening aspects of different perspectives towards an unproblematic single 'forward'. In contrast, the hat disposition invites teachers/learners to develop the stamina for the 
difficulties of the long-haul of developing intercultural capacities for digging deeper and relating wider as we face the storm of the more-than-wicked collective challenges we will need to face together.

This cartography has been used in a research project in teacher education in a large Canadian university that aimed to analyze dispositions of teacher candidates who engaged in border-crossing field experiences as part of their teacher certification program. The teacher candidates engaged with the cartography as part of a workshop in a learning cycle that involved pre-surveying, a workshop, a service learning practicum in an unfamiliar or international setting, and post-surveying. The workshop was meant to assist teacher candidates in becoming more aware of their responses when engaging in border crossing in various contexts, and to then become more self-reflective about the reasons they have for certain types of dispositional responses. The metaphors provided the meta-language to do this sort of work. Ultimately, the workshop was encouraging teacher candidates to then engage more self-reflexively with their own relation to matters of societal inequality and power that emerge in these contexts, and how this relates to certain patterns of dispositions. The findings of this research affirmed the limits of interculturality as is dominantly framed. The majority of participants saw themselves as open to learning and engaging with diversity, and reported a recognition and desire to address multiple inequalities operating in society. However, analysis of educationally contextualized responses revealed a thorough mismatch with these stated desires. In their role as educators, the majority of respondents normalized systemic material inequality and racial privilege; and maintained that curricular space should be framed from Eurocentric orientations. The language that was used to support and explain ideas about inequalities, and ways of thinking in education, was achieved through dominant discourses that reflect a Eurocentric orientation. Teacher candidates' engagement with what is 'other' through educational scenarios was accomplished through a deficit perspective that served to reaffirm inequitable structures and ignored their own privileged positions within these structures (see Kerr \& Andreotti, 2019).

Cartography 3 - Affective dispositions towards complexity: splashing, floating, ducking. diving

Decolonizing intercultural education (Gorski 2008) is an uncomfortable process as it requires teacher candidates to intensively 'examine and respond to the complexities of their particular socio-political contexts' as well as their own investments in these modern/colonial structures (Zembylas and Papamichael 2017, p. 1). While there is rich literature on 'pedagogies of discomfort' in general (e.g., Amsler 2011; Boler 1999; Cuti \& Whiting 2015; Ohito 2016; Zembylas 2015, 2017), there is little practical guidance for teachers who wish to address the specific cognitive, affective and ontological discomforts of interrupting modern/colonial violences in intercultural educational practice. Members of the GTDF collective created the 'beach' cartography (Fig. 3) to support teacher candidates who expressed fears of 'drowning' in uncertainty and incapability as they became aware of and faced with the inequalities, complexities, contradictions and complicities of intercultural learning in ecological and global justice work within their own educational practice.

The cartography illustrates four affective positions in relation to colonial complexity and contradiction, the more secure-feeling of which we represent as being partly on or close to land ('splashing'), and the more uncertain-feeling of which are represented as 'in 
water' ('floating', 'ducking' and 'diving'). Each position is associated with a different level of engagement, ranging from the 'informational' (constructing what is happening) to the 'ontological' (reflecting on the implications of how we and other beings exist in the world). The metaphor is complemented by sets of questions designed to help teachers 'dive deeper' at each level of engagement. The remainder of this section illustrates how this cartography can be used to support moves towards engagements with interculturality that can interrupt rather than reproduce patterns of social and ecological violence in teacher education.

[insert figure 3: The beach (adapted from https://decolonialfutures.net/portfolio/thebeach/ )]

Teachers in a 'splashing' position are tentatively testing the waters of a complex issue. In the field of intercultural education, this may be, for example, the ethical complexities of teaching in multicultural and plurilingual classrooms (Zembylas and Papamichael 2017), addressing epistemic and ontological injustices when designing pedagogies for 'global citizenship education' (Pashby 2015) or working with young people facing the enormity of climate crisis in a simultaneously connected and divided world (Ojala 2016). In this position, we thirst for more information about an issue, such as what a problem is, and how it affects us and others.

Those in a 'floating' position move beyond the informational zone to find a comfortable space, past the breaking point of the waves, where they can problematize information while remaining in control of their and others' knowledge. Here, teachers may seek out tested pedagogies for intercultural learning as 'solutions' to their problems; for example, national guidance on anti-racist practice for teachers that promises to address underlying structures of 'nationalism, racism and intolerance' in schools (Zembylas and Paramichael 2017), or pedagogies of complexity that aim help young people formulate systemic critiques of their own complicities in systems of power (Pashby 2015). The hope of 'floating' is that a correct, unambiguous and authoritative response to an issue can effectively guide personal practice and policy towards already-desired outcomes without mess or entanglements in modern/colonial power structures. To deepen and trouble this desire, we can therefore ask methodological questions that reveal its limits, such as: What strategies are effective? How can outcomes be objectively measured? How to improve effectiveness? What obstacles prevent success? What knowledge/expertise/data/ is missing? What policy is needed or not being implemented correctly?

Teachers in a 'ducking' position may already have begun to feel uncomfortable with the contradictions of the methodological approach, and to put their heads under water with eyes open to the deeper issues that problematize what they expect or wish to see. An example is the hope or belief that the effects of globally systemic violence on marginalized young people can be effectively addressed through personal practice in a teacher's control or through state policy (where the state itself is regarded as outside these relations). In this position, people may have a tangible fear of drowning in the murkiness of complexity, complicity, ambivalence, paradox and uncertainty. Here, we can raise questions to help teacher candidates 'dive deeper' into the epistemological dimensions of interculturality, specifically problematizing their own ways of knowing. 
Such questions may include: Who decides in which direction to move? In whose name; for whose benefit; as part of which historical processes? How are the voices of those who have been wounded in these processes, and those who dissent them, included (or not) in the approach? How is the way I know this issue part of the problem? What assumptions are we taking for granted? How can we work across difference and collaborate without requiring consensus amidst complexity and contradiction?

Finally, when moving from a 'ducking' to 'diving' position, we can pose questions that help teacher candidates see, face and explore the deep structures which tether intercultural education to the modern/colonial imaginary, especially affective investments in, sanctioned ignorances about and complicities with systemic relations of colonial violence which are reproduced through the very ways we feel and relate to each other. Questions to deepen engagement at this level include: What are we deeply attached to and why? What cultural ignorances are we continuing to embody? What fantasies/delusions are we invested in? What are our perceived entitlements? How are we being accountable to future generations? As we develop the stamina, breathing capacity, visual acuity and diving techniques to spend more time under water, we may also start to ask more ontological questions about how we are in the world, such as: Who are we beyond our perceptions, self-images and categories of thought? How can we disarm and de-center in order to be able to 'be with' where we are and what is in front of us? Who is bearing the costs of my learning and its pace? How do we awaken our underused or exiled senses? How do we make space for the land to imagine/dream/design through us? What can we learn from the failures, limitations and successes of this experiment?

The 'beach' metaphor allows us to visualize teacher candidates' different levels of readiness for deepening their engagement with the systemic roots of contemporary global challenges. It is a practical tool which can enable them to face complexity, uncertainty, paradoxes and a plurality of perspectives; to work with their body and its range of senses; to relate to their own and others' knowledge in discerning and experimental ways; and to relate beyond identity, knowledge and understanding - all of which are critical capabilities for interculturally oriented educators. We argue that such a tool can support teacher candidates to 'learn to dive' into (rather than 'drown in') the complexities of global power in their everyday practices through working generatively with affective investments throughout the journey.

\section{Conclusion}

At present, the prevailing frameworks for teacher education in our contexts are not oriented towards supporting teachers to venture beyond the safe (if shifting) sands of identifying and solving measurable problems in their classrooms, nor engaging with the openness of the straw hat. In English schools, for example, there is a combination of metricised accountability, punitive performance management, methodologically individualist and nationalist educational league table competition, prioritization of evidence-based research and pedagogy, and the depoliticization of pedagogical training. These combine to create fearful and conservative learning environments in which critical questioning, systemic analysis, experimental pedagogies, and emergent processes of change are invisibilized, discouraged or repressed. This 'neoliberal condition' is common in Canada and the UK, and is widely criticised and understood to contribute to educational inequality, teachers' de-professionalisation, mental and physical illness, and difficulty coping with complexity and complicity in systemic harm (Osberg \& Biesta, 2010; Thomson, Hall \& Jones, 2010; Tuck, 2013; Yoon \& Lubienski, 2017). Resistance to 
these repressive practices is also recognised as an important site of struggle in education (Ball, 2016; Hall \& McGinty, 2015; Tett \& Hamilton, 2019). However, while learning to resist neoliberal policies can support teachers to duck into epistemological questions and engage with an epistemic openness of the straw hat, stretching this inquiry into ontological questions about how both these policies and teachers' complicities with and resistances to them are integral parts of ongoing modern/colonial violence opens possibilities to transformations that are not yet imaginable. Engaging educators in consideration of our deep affective and physical investments in modernity/coloniality's logics, as well as in the deeper relations of separability that underlie these neoliberal policies, may open possibilities for learning that could make decolonial gestures possible.

It is not easy to engage interculturality as we are suggesting in educational institutions today. In the North American context, 'a culture of pragmatism dissuades theoretical or philosophical discourses among educators in favour of those focused on immediate, practical strategies' (Gorski, 2008, p.521). In the UK, possibilities for deeper and more challenging intercultural education have been repressed by neoliberal and anti-liberal government agendas, the state-led repression of critical social analysis and pedagogy in schools, and an intensified focus on the regulation and measurement of educational 'quality, standards and basic skills' (Ward, 2006), as well as a deeply enduring ignorance about and attachment to Empire (Booth 2020; Tomlinson 2019). In the Canadian context, similar technocractic practices barriers are experienced (Kerr, 2014), but decolonial priorities are particularly difficult to engage due to influential narratives that promote a multicultural innocence that celebrates the inherent goodness of the white Canadian settler nation-state as the purveyor of rights to the cultural 'other' (Mackey, 2002; St. Denis, 2011). Multicultural discourses in Canada work to reinforce a dominant white, Western, liberal cultural centre in the Canadian nation-state and schools, and create an 'exalted' subjectivity for members of that cultural group who are perceived as inherently good in beneficently purveying equality and justice to the cultural 'other' (Thobani, 2007). Within these discourses the violences of settler-colonialism become invisibilized, as well as Settler material privilege and systemic racism (Tuck \& Yang, 2012). These narratives and related discourses circulate in schools (St. Denis, 2011), and create substantial affective barriers for teachers to see and address inequalities.

Furthermore, while there are already high levels of discomfort, anxiety, sadness and fear about the future circulating throughout all levels of education in Canada, the United Kingdom and the United States (Campbell, 2018; Gibson, 2019; Walker, 2018), these intensify within ecological, climate change, global justice, and multicultural and intercultural education specifically (Ojala, 2012; 2016; Zembylas, 2015; Zembylas \& Papamichael, 2017). Yet precisely in these contexts in which such anxieties prevail, there is generally little support for intercultural education 'that acknowledges teachers' discomfort and responds to it pedagogically' (Zembylas \& Papamichael, 2017, p. 1), and little recognition or space for 'battling explicitly against the prevailing social order with intercultural education' (Gorski 2008, p. 516).

One approach that has helped us when working with teachers facing these more-thanwicked global challenges within current modernist systems is to introduce the 'gesture' as a mode of response. Moving from affective dispositions of defensiveness, ethnocentrism and paternalism, towards selective openness and ultimately affectability in any context of intercultural learning takes time, courage and humility. It also defies 
strategic plans or simplistic and satisfying solutions. So, too, does deepening the way we engage with complex systems of modern violence by shifting desires from needing more information to improve the effectiveness or efficiency of the system, towards disinvesting from it to open up possibilities of not-yet-imaginable realities. Gestures, which are embodied, non-verbal or more-than-verbal, open-ended expressions of meaning that indicate 'intention rather than full-blown... arguments' (Naranch, 2009, p.36), can play a special role in the messy, uncomfortable, durational, unguaranteed and always-already compromised process of trying to heal the wounds of systemic colonial violence in intercultural learning itself. While we do not already know how to do this necessary work, following Mignolo, we may undertake action (including learning, unlearning, detoxifying, decluttering, mourning, grieving, healing and composting within our individual and collective bodies) 'that directly or indirectly engages in disobeying the dictates of the colonial matrix and contributes to building of the human species on the planet in harmony with the life in/of the planet on which the human species is only a minimal part and of which it depends' (Mignolo, 2014). As illustrated in this paper, we believe that pedagogical tools that enable teacher candidates in our settler-colonial and post-imperial contexts to expand their understanding of cultural and ecological relationships are crucial. The pedagogical experiments we have shared provide opportunity to engage with teacher candidates beyond the existing frameworks of modernist knowledge, politics, and economic systems, and offer possibilities for decolonial futures not yet imagined.

\section{Works cited}

Ahenakew, C. R. (2017). 'Mapping and complicating conversations about Indigenous education', Diaspora, Indigenous and Minority Education, 11(2): 80-91.

Amsler, S. (2011). From 'therapeutic' to political education: the centrality of affective sensibility in critical pedagogy. Critical Studies in Education, 52(1): 47-63,

Amsler, S. (2019). Gesturing towards radical futurity in education for alternative futures. Sustainability Science, 14: 925-30.

Andreotti, V. (2012). Education, knowledge and the righting of wrongs. Other Education: The Journal of Educational Alternatives, 1(1): 19-31.

Andreotti, V., Fa'Afoi, A., Sitomaniemi-San, J. \& Ahenakew, C. (2014). Cognition, affect and relationality: experiences of student teachers in a course on multiculturalism in primary teacher education in Aotearoa/New Zealand. Race, Ethnicity and Education, 17(5): 706-28.

Andreotti, V., Stein, S., Ahenakew, C., \& Hunt, D. (2015). Mapping interpretations of decolonization in the context of higher education. Decolonization: Indigeneity, Education \& Society, 4(1), 21-40.

Andreotti, V. \& Pashby, K. (2016). Ethical internationalisation in higher education: interfaces with international development and sustainability. Environmental Education Research, 22(6): 771-87. 
Andreotti, V., Stein, S., Pashby, K. \& Nicholson, M. (2016). Social cartographies as performative devices in research on higher education, Higher Education Research and Development, 35(1): 84-99.

Andreotti, V. \& Suša, R. (2018). Global learning as unlearning: beyond the certainty of knowing as an anchor for the security of being. http://blogs.ubc.ca/gceotherwise/files/2018/04/global-learning-as-unlearning.pdf.

Andreotti, V. \& Suša, R. (2019). Social cartography in educational research. Oxford Research Encyclopedia of Education. London: Oxford University Press.

Andreotti, V., Stein, S., Sutherland, A., Pashby, K, Suša, R., Amsler, S. with the Gesturing Towards Decolonial Futures Collective (2018). Mobilising different conversations about global justice in education: towards alternative futures in uncertain times. Policy \& Practice: A Development Education Review, 26 (Spring), https://www.developmenteducationreview.com/issue/issue-26/mobilising-differentconversations-about-global-justice-education-toward-alternative.

Andreotti, V., Stein, S., Suša, R., Cajkova, T., d'Emilia, D., Jimmy, E., Calhoun, B., Amsler, S., Cardoso, C., Siwek, D., \& Fay, K. (2019). Global citizenship education otherwise. Guelph: Musagetes foundation.

Antier, E. (2019) L'éducation plurilingue et interculturelle au regard des conceptions morales des enseignants de langue-culture en contexte multiculturel', Recherches en didactique des langues et des cultures, 16(2): 1-16.

Antunes, S., Teixeira, S., \& Cruz, M. (2009). De hello ao hallo - uma abordagem intercultural e plurilingual no ensino precoce de línguas estrangeiras. Saber \& Educar, 14.

Ball, S. (2016). Subjectivity as a site of struggle: refusing neoliberalism? British Journal of Sociology of Education, 37(8), 1129-1146.

Baker, M. (2012) Modernity/coloniality and Eurocentric education: towards a postOccidental self-understanding of the present. Policy Futures in Education, 10(1): 422.

Bhambra, G. \& Holmwood, J. (2018). Colonialism, postcolonialism and the liberal welfare state. New Political Economy, 23(5), 574-587.

Boler, M. (1999) Feeling Power: Emotions and Education. New York: Routledge.

Booth, R. (2020) UK more nostalgic for empire than other ex-colonial powers. The

Guardian, 11 March. https://www.theguardian.com/world/2020/mar/11/uk-morenostalgic-for-empire-than-other-ex-colonialpowers?fbclid=IwAR107VWSHAhnk5TcackMIQtThC7k0GzEJuJdFIWFRXpihB8hXUxrboEBN4

Boscardin, C. (2015). Reducing implicit bias through curriculum interventions. Journal of General Internal Medicine, 30(12): 1726-1728.

Campbell, D. (2108). Children face mental health epidemic, say teachers. Guardian, 23 June, https://www.theguardian.com/society/2018/jun/23/schoolchildren-facing-mentalhelp-epidemic. 
Curi, R. \& Whiting, E. (2015) The emotional work of discomfort and vulnerability in multicultural teacher education. Teachers and Teaching: Theory and Practice, 21(8): 1010-1025.

Dervin, F. (2015). Towards post-intercultural teacher education: analysing 'extreme' intercultural dialogue to reconstruct interculturality. European Journal of Teacher Education, 38(1), 71-86.

Donald, D. (2016). From what does ethical relationality flow? An "Indian" Act in three artifacts. In. J. Seidel \& D.W. Jardine (Eds.) The ecological heart of teaching: Radical tales of refuge and renewal for classrooms and communities (pp. 10-16. New York: Peter Lang Publishing.

Dockrill, H., Rahatzad, J. \& Phillion, J. (2016). The benefits and challenges of study abroad in teacher education in a neoliberal context. In Information Resources Management Association (Ed.) Teacher Education: Concepts, Methodologies, Tools and Applications. PA: Information Science Reference.

Dooly, M. A. (2011). Crossing the intercultural borders into $3^{\text {rd }}$ space culture(s): Implications for teacher education in the twenty-first century. Language and Intercultural Communication, 11(4), 319-337.

Driscoll, P., Rowe, J. E., \& Thomae, M. (2014). The sustainable impact of a short comparative teaching placement abroad on primary school language teachers' professional, linguistic and cultural skills. Language Learning Journal, 42(3): 307320.

Faas, D., Hajisoteriou, C. and Angelides, P. (2014). Intercultural education in Europe: policies, practices and trends. British Educational Research Journal, 40(2).

Ferreira da Silva, D. (2019). An end to 'this' world: Denise Ferreira da Silva interviewed by Susanne Leeb and Kerstin Stakemeier, Texte Zur Kunst, 12 April, https://www.textezurkunst.de/articles/interview-ferreira-da-silva/.

Gibson, V. (2019). As more students seek mental health care, they face long waits...', Globe and Mail, 14 February, https://www.theglobeandmail.com/canada/article-facedwith-long-waits-for-mental-health-care-students-and/.

Gorski, P. (2008). Good intentions are not enough: a decolonizing intercultural education. Intercultural Education, 19(6), 515-525.

Gorski, P. (2009). Intercultural education as social justice. Intercultural Education, 20(2), 87-90.

Grosfoguel, R. (2007). The epistemic decolonial turn. Cultural Studies, 21(2-3), 211-223.

Grosfoguel, R. (2012). The dilemmas of ethnic studies in the United States: Between Liberal multiculturalism, identity politics, disciplinary colonization, and decolonial epistemologies. Human Architecture: Journal of the Sociology of Self-Knowledge, 10(1), 81-90.

Hall, D. and McGinty, R. (2015). Conceptualizing teacher professional identity in neoliberal times: resistance, compliance and reform. Education Policy Analysis Archives, 23. Retrieved at: https://epaa.asu.edu/ojs/article/view/2092. 
Hartley, D. (2000). Shoring up the pillars of modernity: teacher education and the quest for certainty. International Studies in Sociology of Education, 10(2): 113-31.

Holm, G. and Zilliacus, H. (2009). Multicultural education and intercultural education: is there a difference? In Talib, M. T., Loima, J., Paavola, H., Patrikainen, S. (Eds) Dialogs on Diversity and Global Education, Frankfurt am Main: Peter Lang.

Jackson, J. (2015). Preparing students for the global workforce: the impact of a semester abroad', Language and Intercultural Communication, 15(1), 76-91.

Jiang, X. (2011). Why interculturalisation? A neo-Marxist approach to accommodate cultural diversity in higher education. Educational Philosophy and Theory, 43(4): 387399.

Kerr, J. (2014). Western epistemic dominance and colonial structures: considerations for thought and practice in programs of teacher education. Decolonization: Indigeneity, Education \& Society, 3(2), 83-104.

Kerr, J. \& Andreotti, V. (2018). Recognizing more-than-human relations in social justice research: Gesturing towards decolonial possibilities. Issues in Teacher Education, 27(2), 53-67.

Kerr, J. \& Andreotti, V. (2019). Crossing borders in initial teacher education: Mapping dispositions to diversity and inequity. Race Ethnicity and Education, 22(5), 647-665. DOI 10.1080/13613324.2017.1395326

Liebman, M. \& Paulston, R.G., (1996). Social cartography: A new metaphor/tool for comparative studies. In R.G. Paulston (Ed.), Social cartography: Mapping ways of seeing social and educational change (pp. 7-28). New York: Garland.

Mackey, E. (2002). In the house of difference: Cultural politics and national identity in Canada. Toronto: University of Toronto Press.

Magos, K., Tsilimeni, T., \& Spanopoulou, K. (2013). 'Good morning, Alex - Kalimera Maria': digital communities and intercultural dimension in early childhood education. Intercultural Education, 24(4), 366-373.

Martin, F. \& Pirbhai-Illich, F. (2016). Towards decolonising teacher education: criticality, relationality and intercultural understanding. Journal of Intercultural Studies, 37(4), 355-72.

Messelink, H. E., van Maele, J. \& Spencer-Oatey, H. (2015). Intercultural competencies: what students in study and placement mobility should be learning. Intercultural Education, 26(1): 62-67.

Mignolo, W. D. (2011). The Darker Side of Western Modernity: Global Futures, Decolonial Options. Durham: Duke University Press.

Mignolo, W. (2014). Looking for the meaning of decolonial gesture. Hemispheric Institute, 11(1). https://hemisphericinstitute.org/en/emisferica-11-1-decolonialgesture.html.

Morrice, L. (2013). Learning and refugees: recognizing the darker side of transformative learning. Adult Education Quarterly: A Journal of Research and Theory, 63(3), 251271. 
Narach, L. (2009). Smart, funny, and romantic? Femininity and feminist gestures in chick flicks'. In L. Goren (Ed.) You've Come a Long Way, Baby: Women, Politics, and Popular Culture. Kentucky: University of Kentucky Press.

National Public Radio Editorial (2016). A silent epidemic: the mental health crisis in our schools. NPR, http://apps.npr.org/mental-health/.

Ochoa, A. (2010). International education in higher education: a developing process of engagement in teacher preparation programs. Teaching Education, 21(1), 103-112.

Ohito, E. (2016). Making the emperor's new clothes visible in anti-racist teacher education: enacting a pedagogy of discomfort with white preservice teachers. Equity \& Excellence in Education, 49(4): 454-467.

Ojala, M. (2012). Regulating worry, promoting hope: how do children, adolescents and young adults cope with climate change? International Journal of Environmental and Science Education, 7(4), 537-61.

Ojala, M. (2016). Facing anxiety in climate change education: from therapeutic practice to hopeful transgressive learning. Canadian Journal of Environmental Education, 21, 41-56.

Osberg, D. and Biesta, G. (2010). Complexity Theory and the Politics of Education. Rotterdam: Sense Publishers.

Pagani, C., Robustelli, F. \& Martinelli, C. (2011). School, cultural diversity, multiculturalism and contact. Intercultural Education, 22(4), 337-349.

Pashby, K. (2015). Conflations, possibilities, and foreclosures: global citizenship education in a multicultural context. Curriculum Inquiry, 45(4): 345-366.

Pashby, K. \& Andreotti, V. (2016). Ethical internationalisation in higher education: interfaces with international development and sustainability. Environmental Education Research, 22(6), 771-87.

Pashby, K. \& Sund, L. (2020). Bridging 4.7 with secondary teachers: engaging critical scholarship in education for sustainable development and global citizenship. In Bamber, P. (Ed), Teacher Education for Sustainable Development and Global Citizenship. London: Routledge.

Paulston, R. (2000). A spatial turn in comparative education? Constructing a social cartography of difference. In J. Schriewer (Ed.) Discourse Formation in Comparative Education, (pp. 297-354). New York: Peter Lang.

Paulston, R.G. (2009). Mapping comparative education after postmodernity. In R. Cowen \& A.M. Kazamias (Eds.), International handbook of comparative education (pp. 965-990). Dordrecht: Springer.

Paulston, R.G., \& Liebman, M. (1994). An invitation to postmodern social cartography. Comparative Education Review, 38(2), 215-232.

Pitt, A. \& Britzman, D. (2003). Speculations on qualities of difficult knowledge in teaching and learning: An experiment in psychoanalytic research. Qualitative Studies in Education, 16(6), 755-776. 
Quin, J. (2009). Growing social justice educators: a pedagogical framework for Social Justice Education. Intercultural Education, 20(2), 109-125.

Rittl, H. and Webber, M. (1973). Dilemmas in a general theory of planning. Policy Sciences, 4(2), 155-169.

Rust, V. and Kenderes, A. (2011). Paulston and paradigms. In J. Weidman and W. J. Jacob (eds) Beyond the Comparative: Advancing Theory and Its Application to Practice, London: Springer.

Schwarzer, D. \& Bridglall, B. (2015). Promoting Global Competence and Social Justice in Teacher Education: Successes and Challenges within Local and International Contexts. Lexington Books.

Scott, D. (2004). Conscripts of Modernity: The Tragedy of Colonial Enlightenment, Durham: Duke University Press.

Shallcross, T. \& Robinson, J. (2007). Is a decade of teacher education for sustainable development essential for survival? Journal of Education for Teaching, 33(2),137147.

Simpson, L. (2014). Land as pedagogy: Nishnaabeg intelligence and rebellious transformation. Decolonization: Indigeneity, Education \& Society, 3(3), 1-25.

Siperstein, S. (2015). Finding hope and gratitude in the climate change classroom. The Journal of Sustainability Education, 30 November, http://www.susted.com/wordpress/content/finding-hope-and-gratitude-in-the-climatechange-classroom $201511 /$.

St. Denis, V. (2011). Silencing Aboriginal curricular content and perspectives through multiculturalism: 'There are other children here'. Review of Education, Pedagogy, and Cultural Studies, 33(4), 306-317

Stein, S. (2019a). Beyond higher education as we know it: gesturing towards decolonial horizons of possibility. Studies in Philosophy and Education, 38, 143-61.

Stein, S. (2018b). Navigating different theories of change for higher education in volatile times. Educational Studies, 55(6): 667-688.

Stein, S., Andreotti, V.D.O., \& Suša, R. (2016) 'Beyond 2015', within the modern/colonial global imaginary? Global development and higher education. Critical Studies in Education, DOI: 10.1080/17508487.2016.1247737.

Stein, S., Hunt, D., Suša, R. \& Andreotti, V. (2017). The educational challenge of unravelling the fantasies of ontological security. Diaspora, Indigenous, and Minority Education, 11(2), 69-79.

Stokke, C. \& Lybæk, L. (2018). Combining intercultural dialogue and critical multiculturalism. Ethnicities, 18(1), 70-85.

Tett, L. \& Hamilton, M. (2019). Resisting Neoliberalism in Education: Local, National and Transnational Perspectives. London: Policy Press. 
Thomson, P., Hall, C. \& Jones, K. (2010). Maggie's day: a small-scale analysis of English education policy. Journal of Education Policy, 25(5), 639-656.

Tillmanns, T. (2019). Learning sustainability as an effect of disruption', Environmental Education Research. DOI: https://doiorg.ezproxy.nottingham.ac.uk/10.1080/13504622.2019.1682125

Tomlinson, S. (2019). Education and Race from Empire to Brexit, Bristol Policy Press.

Tuck, E. (2013). Neoliberalism as nihilism: A commentary on educational accountability, teacher education, and school reform. Journal for Critical Education Policy Studies, 11(2), 324-347.

Tuck, E., \& Yang, K. W. (2012) Decolonization is not a metaphor. Decolonization: Indigeneity, Education \& Society, 1(1), 1-40.

UK Department for Education (2012) Teachers' Standards, https://assets.publishing.service.gov.uk/government/uploads/system/uploads/attachm ent data/file/665522/Teachers standard information.pdf

UNESCO (2006) UNESCO Guidelines on Intercultural Education, Paris: Unesco, https://unesdoc.unesco.org/ark:/48223/pf0000147878.

Walker, T. (2018). Are schools ready to tackle the mental health crisis? National Education Association Today, 13 September, http://neatoday.org/2018/09/13/mentalhealth-in-schools/.

Ward, S. (1998). Intercultural education and teacher education in the United Kingdom: a case of reversible decline'. European Journal of Intercultural Studies, 1, 41-52.

Yoon, E., \& Lubienski, C. (2017). How do marginalized families engage in school choice in inequitable urban landscapes? A critical geographic approach. Education Policy Analysis Archives, 25(42), 1-21.

Zembylas, M. (2015). 'Pedagogy of discomfort' and its ethical implications: the tensions of ethical violence in social justice education. Ethics and Education, 10(2), 163-74.

Zembylas, M. (2017) Teacher resistance to engage with 'alternative' perspectives of difficult histories: the limits and prospects of affective disruption. Discourse: Studies in the Cultural Politics of Education, 38(5): 659-675.

Zembylas, M. and Papamichael, E. (2017). Pedagogies of discomfort and empathy in multicultural teacher education. Intercultural Education, 28(1), 1-19. 
Figure 1: The house modernity built
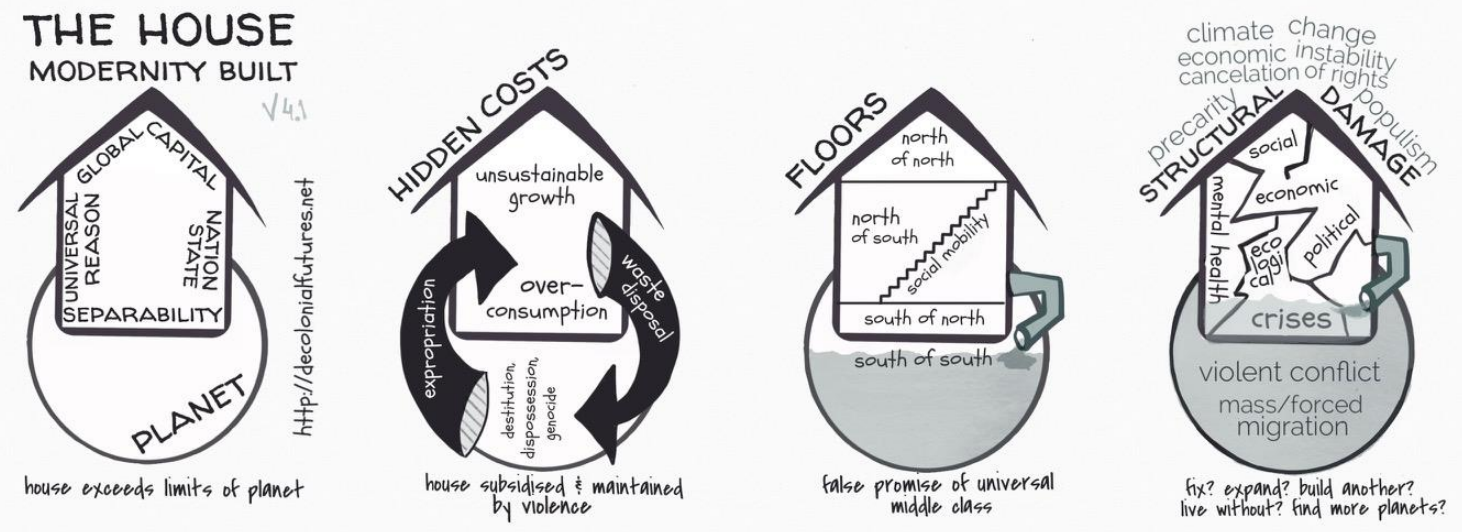

https://decolonialfutures.net/portfolio/mini-zine-house-mycelium/

Figure 2: Social cartography: dispositions of engagement with crossing borders

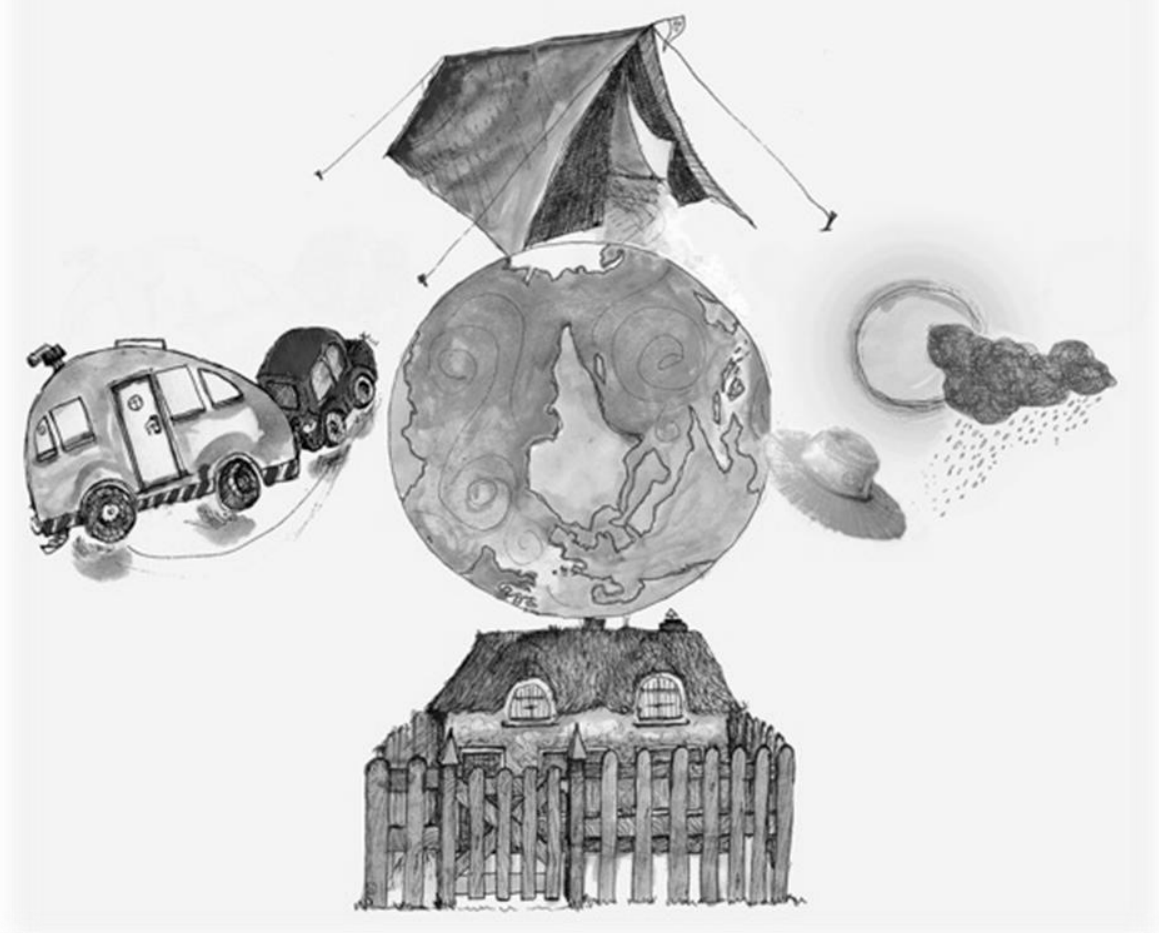


Figure 3: The beach

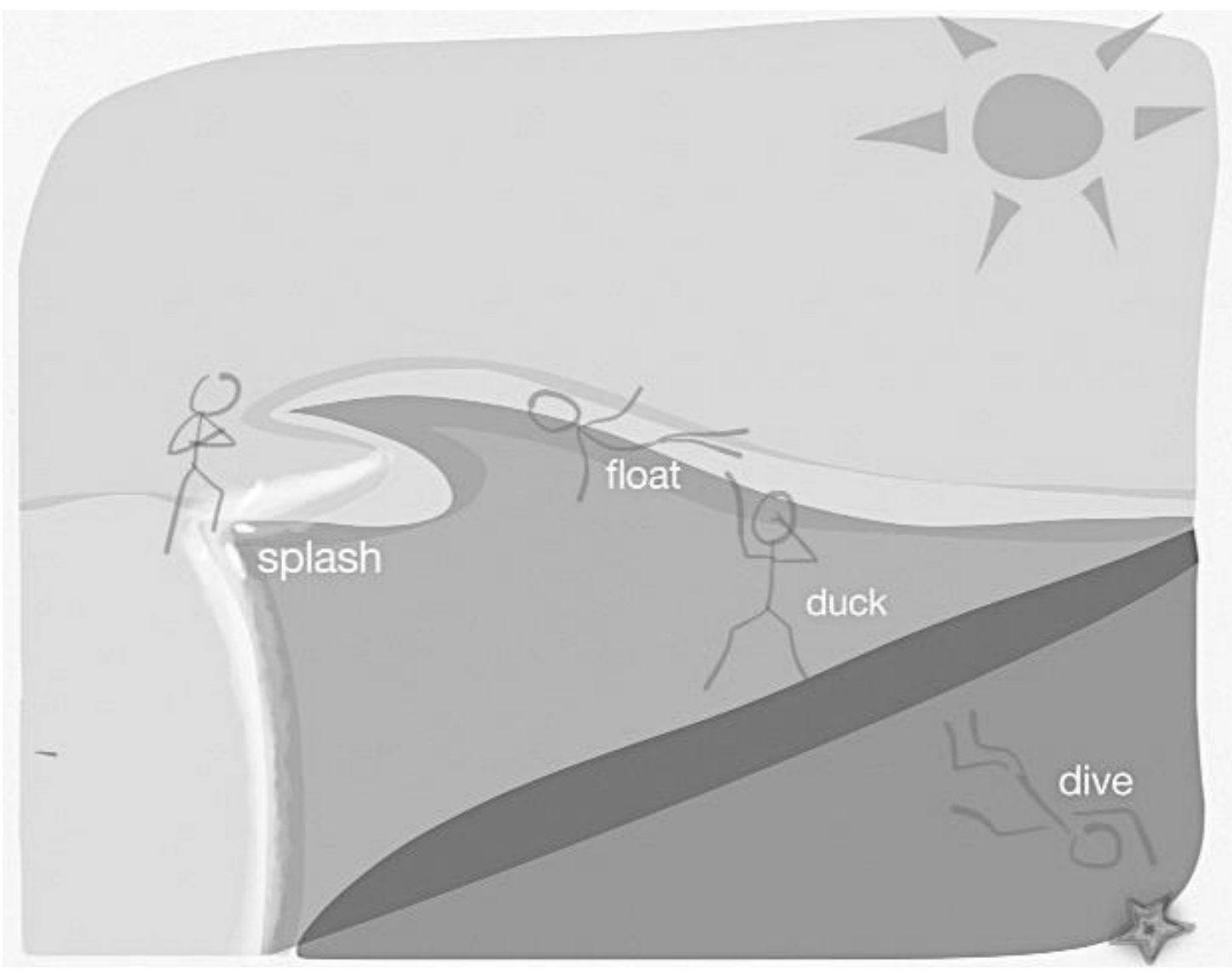

https://decolonialfutures.net/portfolio/the-beach/

\section{Notes}

1 'Gesturing toward decolonial futures' is the name of collective of artists, educators, artist-educators and scholars that facilitates artistic, pedagogical and cartographic experiments which seek to not only imagine but also enact the world differently. Our work proposes a form of analysis that does not trace the roots of contemporary crises to the collapse of a post-War state-capital compromise, to growing inequalities, or to looming climate disaster, despite these being real concerns with real psychic and material impacts. Instead, we argue that these are symptoms of a deeper illness: a global modern/colonial imaginary in which being is reduced to knowing, profits take precedent over people, the earth is treated as a resource rather than a living relation, and the shiny promises of states, markets, and Western reason are subsidized by disavowed harms of impoverishment, genocide, and environmental destruction. Our collective therefore operates from the premise that if the problems of the present are created by this modern/colonial imaginary, then responses or solutions formulated within this imaginary will only lead to more of the same. As with all diagnoses, ours invites its 
own proposition - in this case, the possibility of presently unimaginable decolonial futures. For more information and resources, visit our website,

https://decolonialfutures.net/.

2 The "modern/colonial global imaginary" privileges the following: 'the elevation of human beings over the earth; racialized hierarchy of humanity; teleological, Euro-supremacist notions of human development and history; transcendentalization of both the nationstate and the capitalist market as institutions that, even as they may be critiqued and reformed, are accepted as the best of all possible modes of social, economic, and political organization; possessive individualism, and property ownership as the basis of personhood and worthiness; a strictly binary and heteropatriarchal gender and kinship system; objectification and exploitation of "natural resources"; and the universal value of Western reason' (Stein et al. 2016). 